\title{
EDUKASI GAYA HIDUP HALAL DI KALANGAN KOMUNITAS GENERASI MILENIAL
}

\author{
Muhammad Nusran ${ }^{1}$, Puadi Haming ${ }^{2}$, Etik Prihatin ${ }^{3}$, \\ Sitti Musdalifah Hasrin ${ }^{4}$, Nurlaila Abdullah ${ }^{5}$ \\ ${ }^{1}$ Teknik Industri, Universitas Muslim Indonesia, Makassar \\ ${ }^{2}$ Teknik Industri Agro, Politeknik ATI Makassar \\ ${ }^{3}$ Manajemen, Universitas Muslim Indonesia, Makassar \\ ${ }^{4}$ Teknik Industri, Universitas Muslim Indonesia, Makassar \\ ${ }^{5}$ Teknologi Pertanian, Universitas Hasanuddin, Makassar \\ Correspondence Author: muhammad.nusran@umi.ac.id
}

\begin{abstract}
The concept of halal is an important factor that must be considered in the halal lifestyle of Muslim consumers, not only in consuming food, but as a factor of food safety, cleanliness and assurance of quality, quality and nutrition of what is consumed. According to Nusran and Mohd Azemi (2021), Halal is a value system and lifestyle adopted by Muslims. Halal means permissible in Islam-prepared according to certain parameters of Islamic Law. (Fuad Mohd, 2019). Halal lifestyle education is needed as one of the handling of various serious problems that arise due to the low awareness and understanding of young millennial consumers about the halal concept by increasing the empowerment of the millennial generation about the halal lifestyle. This paper is intended to determine the effect of awareness and knowledge of the halal concept on the millennial generation. Descriptive statistics are used to identify respondents' attitudes towards halal food requirements. The method of collecting data in the field uses a questionnaire system and purposive method which is processed by linear regression analysis method. The results of the analysis obtained are that there is a significant relationship between halal certification, halal lifestyle, awareness and knowledge of halal concepts in the millennial generation. Halal lifestyle education affects awareness and knowledge about halal lifestyle. The official halal certificate has a significant effect on the buying interest of millennial consumers. Awareness and understanding of the concept of halal have a low effect on the buying interest of the millennial generation. From the existing data, it can be concluded that the educational activities carried out can increase the knowledge of the millennial generation about the halal lifestyle and understanding of the point of prohibition of food.
\end{abstract}

Keywords: Halal Education, Halal Lifestyle, Halal Certification, Young Generation

Abstrak: Konsep halal merupakan faktor penting yang harus diperhatikan dalam gaya hidup halal konsumen muslim, tidak hanya dalam mengkonsumsi makanan, tetapi sebagai faktor keamanan pangan, kebersihan dan jaminan kualitas, mutu dan gizi pangan dari apa yang dikonsumsi. Menurut Nusran dan Mohd Azemi (2021), Halal adalah sistem nilai dan gaya hidup yang dianut oleh umat Islam. Halal berarti diperbolehkan dalam Islam - disiapkan sesuai dengan parameter tertentu dari Hukum Islam. (Fuad Mohd, 2019). Edukasi gaya hidup Halal diperlukan sebagai salah satu penanganan berbagai permasalahan serius yang muncul akibat rendah nya kesadaran dan pemahaman konsumen muda milenial tentang konsep halal dengan meningkatkan pemberdayaan generasi milenial tentang gaya hidup halal. Tulisan ini dimaksudkan untuk mengetahui pengaruh kesadaran dan pengetahuan konsep halal pada 
generasi milenial. Statistik deskriptif digunakan untuk mengidentifikasi sikap responden terhadap persyaratan makanan halal. Metode pengumpulan data di lapangan menggunakan sistem angket dan metode purposive yang diolah dengan metode analisis regresi linier. Hasil analisis yang diperoleh adalah terdapat hubungan yang signifikan antara sertifikasi halal, gaya hidup halal, kesadaran dan pengetahuan konsep halal pada generasi milenial. Pendidikan gaya hidup halal mempengaruhi kesadaran dan pengetahuan tentang gaya hidup halal. Sertifikat halal resmi berpengaruh signifikan terhadap minat beli konsumen milenial. Kesadaran dan pemahaman konsep halal berpengaruh rendah terhadap minat beli generasi milenial. Dari data yang ada dapat di simpulkan bahwa kegiatan edukasi yang dilakukan dapat meningkatkan pengetahuan generasi milenial tentang gaya hidup halal dan pemahaman tentang titik keharaman makanan.

Kata Kunci: Edukasi Halal, Gaya Hidup Halal, Sertifikasi Halal Dan Generasi Milenial

\section{PENDAHULUAN}

Sejalan dengan ajaran syariah Islam, umat Islam harus memperhatikan pilihan apa yang mereka konsumsi dan juga harus memperhatikan aspek kehalalan serta aspek keamanan. Pada generasi muda, orangtua sebagai penyedia makanan di rumah dan kantin sebagai penyedia makanan sehari-hari selama jam sekolah harus benar-benar memperhatikan dan menjamin kehalalan makanan yang disajikan. Pemahaman mengenai bahan tambahan makanan berbahaya di lingkungan sekolah sangat membantu dalam meningkatkan pemahaman tentang produk halal dan aman bagi kesehatan (Guntarti et al. 2018). Selain itu, produsen pangan mestinya mempunyai kesadaran dan tanggung jawab terhadap produk yang diedarkan, baik aspek pangan (thoyyib) maupun kehalalannya. (Ali, 2016).

Dalam proses pengolahan dan penyimpanan makanan, hal yang perlu diperhatikan yakni makanan tidak boleh terkontaminasi dan bercampur dengan makanan haram atau zat nya walaupun. Dalam menjamin makanan yang baik (thoyyib), pemerintah telah menetapkan regulasi Industri makanan yaitu: UU No.36 Tahun 2009 tentang Kesehatan, UU Pangan (UU RI No.18 tahun 2012), UU Perlindungan Konsumen (UU RI No 7 tahun 1999). Peraturan Kepala Badan Pengawas Obat dan Makanan RI Nomor: HK.03.1.23.04.12.2205 tanggal 5 April 2012 tentang Pedoman Pemberian Sertifikat Produksi Pangan Industri Rumah Tangga (PIRT). Peraturan Kepala Badan Pengawas Obat dan Makanan RI Nomor: HK.03.1.23.04.12.2206 tanggal 5 April 2012 tentang Cara Produksi Pangan yang Baik untuk Industri Rumah Tangga (CPPB-IRT). Pada saat ini juga telah diatur Persyaratan bahan tambahan pangan yang tercantum dalam Peraturan Menteri Kesehatan No.33 tahun 2012, begitu pula sanksi hukumnya.

Rendahnya kesadaran dan pemahaman kaidah halal dan toyyib pada makanan, akan menimbulkan berbagai masalah serius. Nusran, et al. (2018) mengatakan bahwa Kesadaran nasional terhadap Sertifikat Halal saat ini belum mengalami signifikan pengembangan. Stagnasi yang terjadi pada aturan validasi jaminan halal di Indonesia tersebut membutuhkan gerakan nasional agar masyarakat Indonesia cepat mendapat perlindungan dari pemerintah akan pemenuhan haknya sebagai warga negara, dengan fokus pada aturan pangan halal, obatobatan dan kosmetik yang digunakan. Kesadaran halal dipengaruhi oleh beberapa faktor 
seperti halal pengetahuan dengan sering mengikuti perkembangan halal atau acara pameran halal, atau pelatihan halal dan sejenisnya, serta faktor waktu proses sertifikasi halal.

Peraturan pemerintah tentang halal diwujudkan dengan UU No 33 Tahun 2014 tentang Jaminan Produk Halal. Pentingnya pemahaman regulasi tersebut, menjadi kewajiban kita bersama membangun kesadaran, mengedukasi, melakukan pameran sebagai sebuah contoh konkrit dan mendampingi masyarakat agar terhindar dari pangan yang tidak memenuhi persyaratan. Manfaatnya akan membantu pengambilan kebijakan sertifikat halal produk bagi pemerintah dan pihak yang berwenang. Meningkatnya kepercayaan konsumen akan produk yang disertifikasi halal, akan menciptakan loyalitas konsumen pada produk yang beredar di masyarakat dan adanya rasa aman, citra dan dukungan konsumen dalam mengkonsumsi produk yang disertifikasi halal tersebut (M Nusran, 2019)

Selanjutnya dikatakan bahwa dalam menentukan status kehalalan, menurut Nusran (2018) dalam Supratikno (2017) bahwa status fisiologis hewan sangat berpengaruh terhadap kualitas daging yang dihasilkan. Penanganan yang tidak mensejahterakan pada saat sebelum dan selama proses penyembelihan akan menimbulkan stres dan mengaktifkan sistem simpatis. Pada saat stress, darah akan lebih banyak mengalir ke otak dan otot rangka dan sistem simpatis akan bekerja memposisikan darah. Jika hewan dalam kondisi ini disembelih maka proses kematiannya menjadi tidak berkualitas, hewan itu dirontokkan sehingga dagingnya menjadi memar dan tertinggal darah di dalam daging.

Jika jumlah potensi halal meningkat, maka alur produk dalam proses sertifikasi halal akan meningkat secara signifikan. Jika dibuatkan skenario ditambah kebijakan kadaluarsa maka grafik kenaikan produk bersertifikat akan lebih stabil karena tidak menambah beban Auditor. (Nusran,dkk 2018). Maka Model kebijakan diperoleh berdasarkan simulasi Sistem Dinamika menunjukkan bahwa dari sekitar $80 \%$ daging sapi yang dipotong oleh penyembelih, tidak bersertifikat halal. Sehingga tingkat kesadaran masyarakat (konsumen) mempengaruhi konsumsi daging sapi halal yang di konsumsi.

Dalam meningkatkan pentingnya sertifikasi halal, masih ada sejumlah isu kebijakan seperti itu seperti proses pemotongan syar'i yang tidak merata, dimana produsen tidak dapat menampilkan produk daging sapi sebagai produk halal dan dijamin halal. Pelatihan Juleha meningkatkan kepastian produksi daging sapi halal, karena perlu kehalalan produk daging sapi semakin menunjukkan peningkatan yang signifikan. (Nusran, dkk 2018). Dalam proses Penyembelihan harus memiliki kriteria khusus itu sesuai dengan Syariah Islam, yaitu pelakunya harus muslim, balig dan mengerti caranya Proses penyembelihan berjalan baik tanpa adanya unsur penyiksaan. Setiap RPH diharuskan memiliki penyembelih yang telah memiliki sertifikathalal sebagai penyembelih profesional dan disesuai dengan kriteria khusus. Ini karena itu memberikan Jaminan kepada RPH untuk memproduksi daging halal (Nusran, dkk, 2019)

Adanya label halal yang tidak diikuti dengan pemenuhan persyaratan untuk menjamin produk yang dihasilkan tersebut halal menjadi masalah tersendiri. Saat ini persepsi kehalalan makanan telah berubah, semula hanya terkait ada atau tidaknya produk babi atau alkohol. Sehubungan dengan penggunaan bahan tambahan makanan, pada teknologi pengolahan pangan telah mengubah persepsi tersebut. Proses pengolahan juga dapat menjadi titik kritis keharaman makanan tersebut. Contohnya gula refinasi yang digunakan sebagai pemanis 
makanan pada industri makanan. Gula refinasi mempunyai titik kritis pada proses penghilangan warna yang menggunakan arang aktif. Jika arang aktif ini berasal karbon kayu, maka tidak masalah., namun jika karbon aktif tersebut terbuat dari tulang hewan, hal itu harus dipastikan kehalalan hewannya, apalagi kalau bersumber dari babi.(LPPOM MUI, 2018). Contoh BTM seperti flavor (perisa), anti cacking agent, coloring agent, dan zat aditif lain pada industri makanan menjadi titik kritis untuk penentuan halal tidaknya produk makanan. Contohnya propilen glikol, traicetin, gliserin dapat menjadi titik kritis pada produk makanan yang beredar, karena zat-zat tersebut bisa terbuat dari lemak babi atau lemak hewan lain (Sukardi, 2019).

Maka upaya pencegahan terjadinya hal-hal yang merugikan bagi masyarakat maupun pelaku usaha UMKM makanan dan minuman ini tidak hanya menjadi tanggung jawab pemerintah saja melainkan seluruh masyarakat, termasuk Perguruan Tinggi. Salah satu bentuk pengabdian yang dapat dilakukan adalah edukasi kepada masyarakat dalam hal ini pemilihan makanan dan minuman yang aman dan gaya hidup sehat. Disamping itu, perlu juga diperhatikan kehalalan makanan maupun minuman yang dikonsumsi setiap hari.

Edukasi dapat dilakukan dengan berbagai cara di antaranya adalah penyuluhan dengan menggunakan media penyuluhan yang menarik dan interaktif sehingga akan memberikan hasil pemahaman yang lebih baik. Tujuan pengabdian masyarakat ini untuk meningkatkan pemberdayaan masyarakat tentang halal lifestyle (gaya hidup halal) dan titik kritis keharaman makanan terutama pada generasi muda.

\section{METODE}

Kegiatan dilakukan melalui dua tahap yaitu tahap persiapan dan tahap pelaksanaan yang akan dijelaskan seperti di bawah ini:

\section{Tahap Persiapan}

1. Tim Pengabdian mengadakan rapat koordinasi tim untuk persiapan, dengan memperhatikan, permasalahan yang terjadi di mitra, mendiskusikannya, serta mencari solusi yang dapat ditawarkan kepada mitra. Solusi tersebut mencakup aspek kognitif dan afektif untuk mengatasi permasalahan.

2. Tahap koordinasi pelaksanaan dengan mitra. Pelaksanaan pengabdian masyarakat berkordinasi dengan mitra, membahas tentang prioritas masalah yang dihadapi, upaya pemecahan dan penyelesaian masalah, tindak lanjut dan evaluasi. Selain itu juga dibahas tentang persiapan edukasi terkait tanggal pelaksanaan, penentuan jumlah peserta, aspek kognitif maupun afektif managerial yang diperlukan, rencana pelatihan, perlengkapan sarana dan prasarana yang dibutuhkan selama kegiatan, persiapan izin dan suratmenyurat yang diperlukan.

Pelaksanaan Kegiatan, Metode pengabdian yang digunakan adalah penyuluhan dengan tujuan membangun edukasi dan peningkatan kesadaran masyarakat, yang dilaksanakan dengan beberapa tahapan.1. Sebagai awal kegiatan, dilakukan pre test online pengetahuan tentang halal lifestyle, sertifikasi halal, titik kritis kehalalan makanan pada peserta penyuluhan diminta untuk mengisi pretest dan online tersebut. Hasil tes ini digunakan untuk menyusun materi penyuluhan. 2. Penyuluhan dilaksanakan dengan pemberian materi oleh dua narasumber dilanjutkan dengan 
diskusi. Terdapat dua judul materi yang disampaikan yaitu mengenai pengenalan halal lifestyle dan pengenalan titik kritis kehalalan makanan. 3. Melakukan evaluasi peningkatan kemampuan peserta melalui pre dan posttest materipenyuluhan. 4. Melakukan analisis hasil pretest online dan pre/post test materi penyuluhan menggunakan software IBM statistics 24 .

Hasil dan Pembahasan, Pengumpulan Data, Sebagai mitra menyadari pentingnya edukasi dan pendampingan yang dilakukan tim, dan telah menyatakan kesediaanya aktif berpartisipasi dengan menyediakan sarana dan prasarana selama pelaksanaan kegiatan. Peserta penyuluhan terdiri dari siswa, guru dan pengelola kantin sekolah. Untuk mengetahui ukuran atau jumlah sampel minimal yang dapat digunakan pada kegiatan pre test online ini digunakan rumus Slovin (Setiyani, 2014).

$$
n=\frac{N}{1+N e^{2}}
$$

Keterangan dimana, $\mathrm{n}=$ Ukuran sampel, $\mathrm{N}=$ Ukuran populasi, e= Error margin (kelonggaran ketidaktelitian. Misalnya $\operatorname{Sig}=0,05$ )

Pada kegiatan yang dilakukan ukuran populasi atau jumlah populasi peserta sebanyak 169 peserta, sehingga dengan menggunakan rumus Slovin, banyaknya sampel atau ukuran sampel minimal yang dapat digunakan adalah :

$$
n=\frac{169}{1+169\left(0,05^{2}\right)}=\frac{169}{1,4225}=118,80=119 \text { peserta }
$$

Berdasarkan perhitungan tersebut jumlah responden minimal yang harus digunakan yaitu 119 responden dari 164 total peserta penyuluhan. Jumlah peserta yang mengisi pre test online sebanyak 122 peserta. Nilai tersebut melebihi batas minimal responden yang harus digunakan. Analisis Karakteristik Responden, dianalisis berdasarkan 3 kriteria. Kriteria responden dilakukan berdasarkan jenis kelamin, usia responden dan jenis pekerjaan;

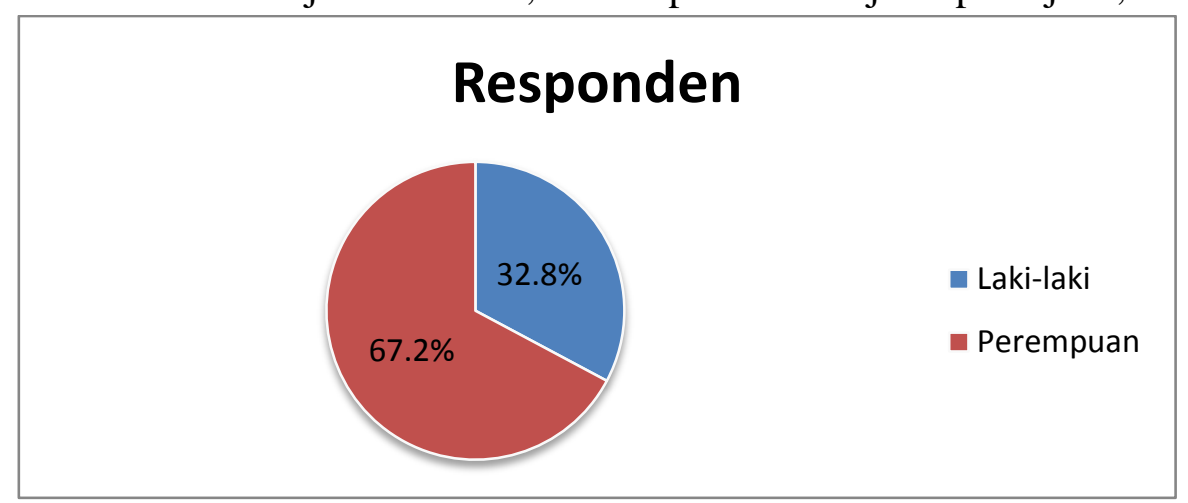

Gambar 1: Karakteristik Responden Berdasarkan Jenis Kelamin

Berdasarkan Gambar 1, responden dengan jenis kelamin perempuan sebesar 67,2 persen sedangkan 32,8 persen adalah laki-laki. Adapun Gambar 2 menunjukkan bahwa mayoritas responden berumur di bawah 15 sampai 18 tahun sebesar 71,3 persen sedangkan responden dengan usia diatas 28 tahun sebesar 27 persen. Gambar 3 menjelaskan karakteristik responen berdasarkan pekerjaannya, dimana 71,3 persen responden mempunyai aktivitas sebagai siswa dan diikuti responden yang beraktivitas sebagai pegawai/karyawan sebesar 28,7 persen. Kedua data ini sesuai dengan target responden pada kegiatan pengmas yaitu siswa (generasi muda). 

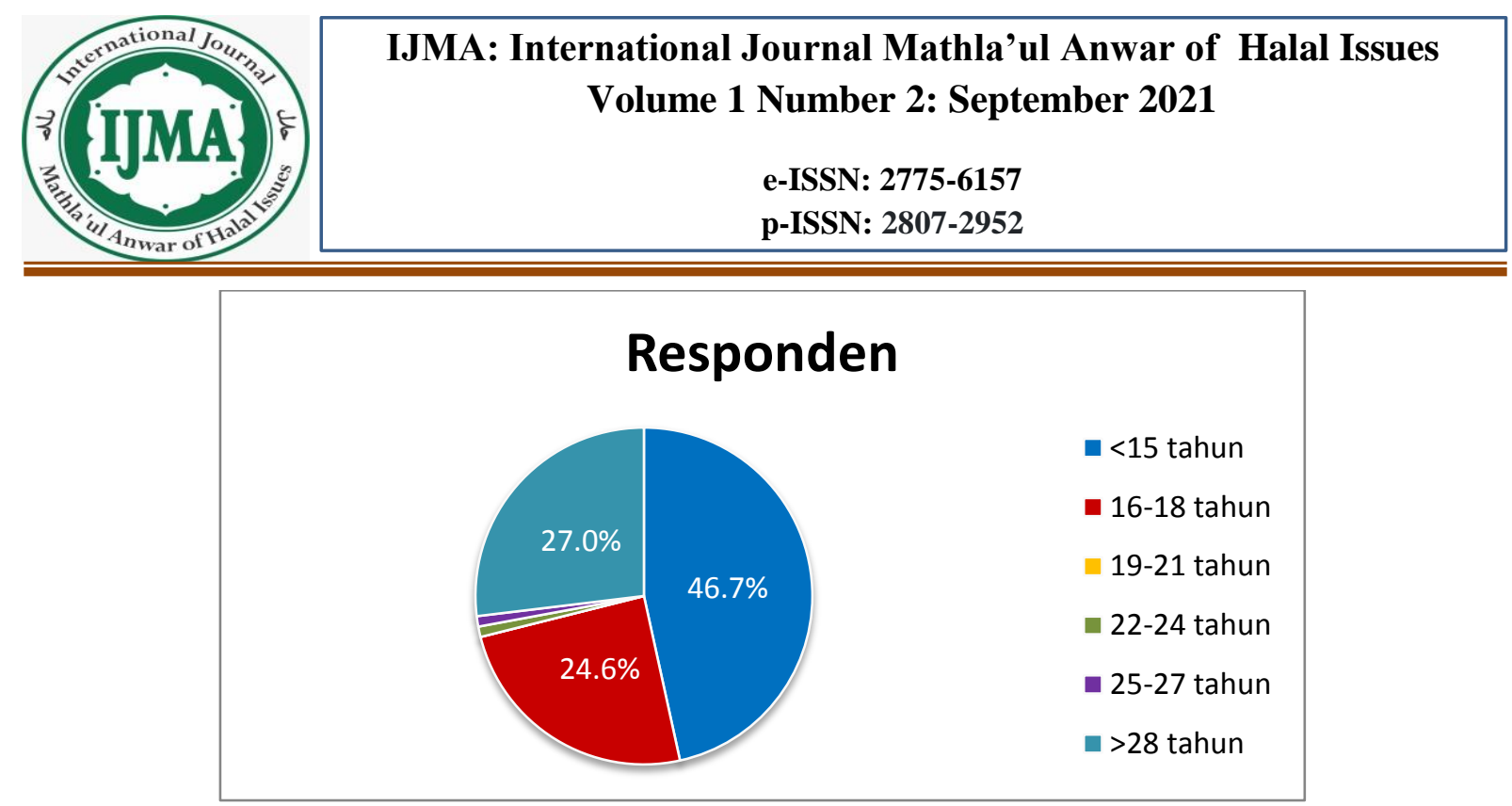

Gambar 2 Karakteristik Responden Berdasarkan Usia

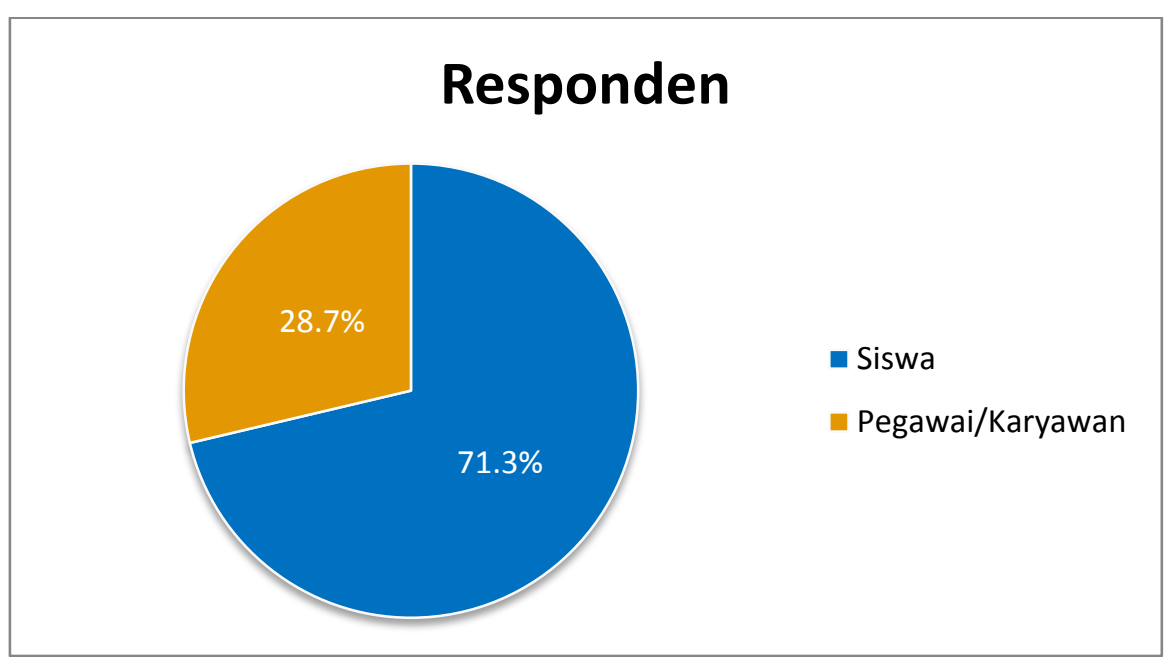

Gambar 3 Karakteristik Responden Berdasarkan Pekerjaan

\section{HASIL DAN PEMBAHASAN}

Hasil Uji Pre-test on-line, Sertifikat halal adalah fatwa tertulis Majelis Ulama Indonesia (MUI) yang menyatakan kehalalan suatu produk sesuai dengan syariat Islam. Tujuan sertifikasi halal pada produk makanan adalah untuk memberikan kepastian kehalalan suatu produk sehingga konsumen merasa aman dan terbebas dari dosa (Ramlan \& Nahrowi, 2014). Hal ini sesuai dengan hasil pre test yang diperoleh, 81,1 persen responden sangat setuju jika logo halal penting dalam kemasan produk makanan, 70,5 persen responden mempertimbangkan logo halal dalam membeli produk, 54,1 persen responden mengetahui logo halal asli dari MUI dan 68.8 peresen ponden sangat setuju untuk mengonsumsi produk berlogo halal. Berdasarkan hal tersebut dapat disimpulkan bahwa responden setuju dengan adaya sertifikasi halal pada produk makanan. Namun terdapat 4,9 persen responden yang belum mengetahui logo halal asli dari MUI dan 2,5 persen responden masih tidak merasa aman dalam mengonsumsi produk berlogo halal.

Kesadaran halal bagi muslim berpengaruh signifikan terhadap minat pembelian konsumen terhadap suatu produk (Yunus et al., 2014). Hasil pada pre test on line ini menunjukkan bahwa 98,4 persen responden menyatakan preferensi terhadap proses penyembelihan dan proses produksi halal. Kemudian, terdapat 99,2 persen responden menyatakan preferensi bahwa makanan halal merupan sesuatu yang penting dalam kehidupan. 
Terkait titik kritis keharaman pada makanan, terdapat 86,9 persen responden menganggap telah mengetahui tentang titik kritis keharaman makanan. Dengan demikian terdapat 13.1 persen yang tidak mengetahui tentang titik keharaman makanan. 90,2 Responden menyetujui bahwa informasi tentang titik keharaman makanan mudah diperoleh. Sisanya seanyak 9,8 persen responden merasa kesulitan mendapatkan informasi terkait titik kritis keharaman pada suatu makanan. Responden juga menyatakan urgensitas informasi terkait titik kritis keharaman. 98 responden juga menyetujui bahwa titik kritis keharaman makanan itu penting untuk diketahui. Hanya ada 1,6 persen responden yang tidak menyetujui hal tersebut.

Komposisi atau komponen makanan yang akan dimakan penting untuk diketahui konsumen. Hal tersebut dapat meningkatkan perilaku halal lifestyle konsumen (Yunus et al., 2014). Pengetahuan responden tentang konsumsi makanan halal menunjukkan hasil bahwa 86-98 persen responden menyatakan penting dalam memperhatikan komposisi dalam makanan, mengetahui komponen tambahan makanan yang tidak halal dan tidak aman dan hanya akan membeli makanan yang jelas aman dan halal berdasarkan bahan-bahan makanan yang digunakan.

Sejumlah 97,5 persen responden menyatakan preferensi bahwa istilah komponen bahan makanan harus lebih sederhana dan mudah dipahami karena hal tersebut mempengaruhi minat beli konsumen. suatu produk mempengaruhi minat beli konsumen. Pada sisi lain, kehalalan suatu produk melalui informasi yang tercantum dalam suatu kemasan akan mempengaruhi keputusan untuk membeli produk. Pada pre test on line ini 99 persen menyatakan preferensi terhadap produk yang berlabel halal. Selain itu, pengalaman membeli produk yang memberikan informasi label halal akan membuat konsumen memberikan rekomendasi kepada konsumen lain. Pada pre test online ini 98 persen akan melakukan hal tersebut jika telah mengkonsumsi produk berlabel halal.

Hasil analisis koefisien determinasi pada hubungan antara sertifikasi halal, kesadaran halal dan komposisi halal terhadap minat beli dicantumkan pada Tabel 1. Tingkat kepercayaan yang digunakan sebesar 95 persen. Koefisien korelasi (r) diperoleh nilai sebesar 0,579. Kondisi ini menunjukkan adanya korelasi yang kuat antara sertifikasi halal, kesadaran halal dan komposisi halal. Koefisien determinasi ( $\mathrm{R}$ square) menunjukkan bahwa sertifikasi halal, kesadaran halal dan komposisi halal yang berpengaruh terhadap minat beli sebesar 33,6 persen.

Pada Tabel 1: Analisis Koefisien Determinasi pada Hubungan antara Sertifikasi Halal, Kesadaran Halal dan Komposisi Halal dengan Minat Beli

Model Summary

\begin{tabular}{ccccc}
\hline Model & R & R Square & Adjusted R Square & Std. Error of the Estimate \\
\hline 1 & $.579^{\mathrm{a}}$ & .336 & .319 & 2.540
\end{tabular}

a. Predictors: (Constant), Komposisi_Makanan (X3), Sertifikasi_Halal (X1), Kesadaran_Halal (X2) 
Pada table Tabel 2, Analisis Regresi Linier dan nilai t hitung pada hubungan antara sertifikasi halal, kesadaran halal dan komposisi halal dengan minat beli

\begin{tabular}{|c|c|c|c|c|c|c|}
\hline \multicolumn{7}{|c|}{ Coefficients $^{\mathrm{a}}$} \\
\hline & \multirow[b]{3}{*}{ Model } & \multirow{2}{*}{\multicolumn{2}{|c|}{ Unstandardized Coefficients }} & \multirow{3}{*}{$\begin{array}{c}\begin{array}{c}\text { Standardized } \\
\text { Coefficients }\end{array} \\
\text { Beta }\end{array}$} & \multirow[b]{3}{*}{ t } & \multirow[b]{3}{*}{ Sig. } \\
\hline & & & & & & \\
\hline & & B & Std. Error & & & \\
\hline \multirow[t]{4}{*}{1} & (Constant) & 10.350 & 1.997 & & 5.182 & .000 \\
\hline & Sertifikasi_Halal(X1) & .453 & .132 & .348 & 3.442 & .001 \\
\hline & Kesadaran_Halal (X2) & .165 & .129 & .147 & 1.277 & .204 \\
\hline & Komposisi_Makanan (X3) & .102 & .067 & .164 & 1.512 & .133 \\
\hline
\end{tabular}

a. Dependent Variable: Minat_Beli (Y)

Persamaan linier yang diperoleh pada kegiatan ini adalah $\mathrm{Y}=0,453 \mathrm{X} 1+0,165 \mathrm{X} 2+$ $0,1026 \mathrm{X} 3+10,350$ (Tabel 2). T-tabel yang digunakan sebesar 1,65754 $(\mathrm{df}=121 ; \alpha=0,05) . \mathrm{T}$ hitung pada sertifikasi halal, kesadaran halal dan komposisi halal masing-masing sebesar 3,442; 1,277 dan 1,512 (Tabel 2). Pada sertifikasi halal t-hitung lebih besar dibandingkan dengan ttabel, namun pada kesadaran halal dan komposisi makanan t-hitung lebih kecil dibandingkan dengan t-tabel. Hal ini menunjukkan bahwa sertifikasi halal mempengaruhi minat beli makanan namun kesadaran halal dan pengetahuan tentang komposisi makanan halal masih rendah dalam hal mempengaruhi keputusan membeli makanan.

Berdasarkan hal tersebut, diketahui bahwa pengetahuan tentang kesadaran halal dan komposisi makanan halal perlu ditingkatkan lagi. Produk bersertifikat halal ditandai dengan adanya logo halal pada kemasan produk. Tercantumnya logo halal pada kemasan menunjukkan informasi bahwa telah dilakukan audit halal dan sertifikasi pada produk tersebut dengan adanya fatwa halal dari Majelis Ulama Indonesia. Pelaku usaha wajib untuk memberikan informasi yang jelas dan jujur bahwa produk yang diperdagangkan adalah produk halal yang telah memperoleh sertifikasi resmi. Hal tersebut sesuai dengan hasil pre-test online yang menyebutkan bahwa sertifikasi halal mempengaruhi responden dalam membeli makanan.

Kesadaran halal yang dalam ini berisi tentang proses pengolahan makanan dan titik kritis keharaman makanan tidak mempengaruhi minat beli responden. Begitu pula dengan pengetahuan tentang komposisi makanan halal juga tidak mempengaruhi minat beli responden. Kesadaran halal dipengaruhi oleh beberapa faktor seperti kepercayaan agama, identitas diri dan informasi media (Yasid et al., 2016). Karena responden yang digunakan pada kegiatan pengmas ini mayoritas anak dibawah umur 15-18 tahun yang mempunyai keterbatasan akses informasi, maka pengetahuan tentang komposisi makanan kurang dapat dipahami oleh para responden.

Komposisi makanan merupakan hal yang penting untuk dipertimbangkan oleh konsumen terutama bagi umat Islam karena hal tersebut akan memberikan informasi terkait titik kritis keharaman. Konsumen yang teliti akan memeriksa komposisi pada bungkus produk atau bahkan bertanya kepada restoran apakah bahan makanan dan alat yang digunakan benar-benar bebas dari unsur-unsur yang melanggar syariat agama Islam (Mutmainah, 2018) . Hal-hal tersebut belum banyak dilakukan oleh responden yang mayoritas berumur anak dibawah umur 15-18 tahun. 
Berdasarkan data, responden mayoritas anak dibawah umur 15-18 tahun kemungkinan hanya melihat logo halal sebagai indikator kehalalan produk sehingga sangat mempengaruhi minat beli. Namun untuk pengetahuan tentang kesadaran halal dan komposisi makanan kurang diketahui anak- anak muda sehingga tidak mempengaruhi mereka dalam membeli makanan. Hasil pretest online ini menjadi dasar penyusunan materi penyuluhan pada masyarakat.

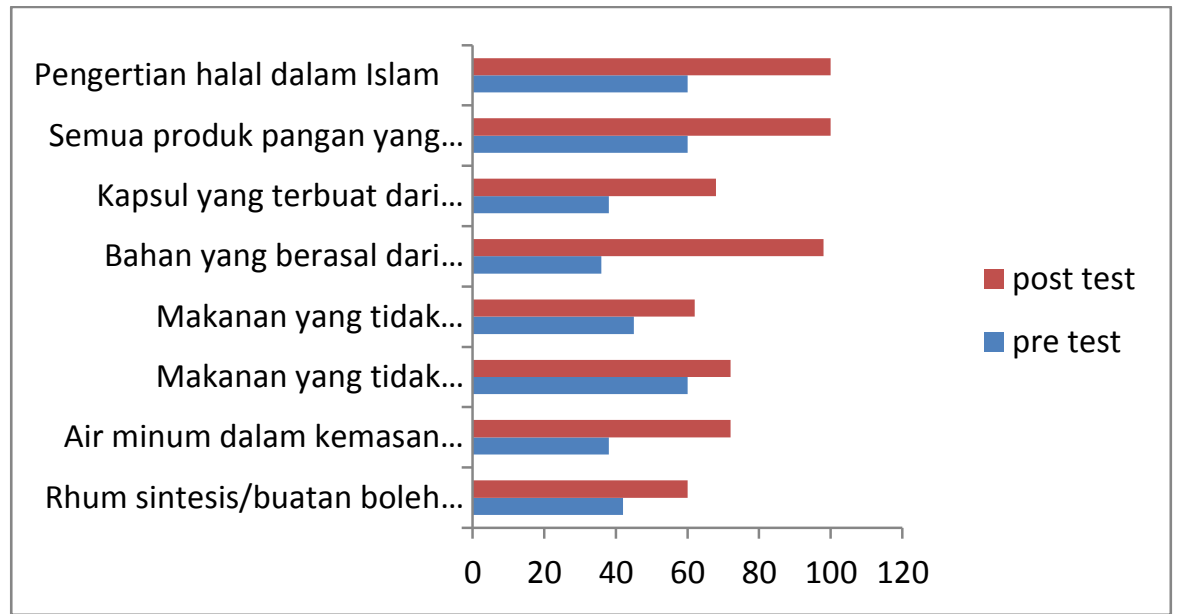

Gambar 4:Hasil analisis pre test dan post test

\section{KESIMPULAN}

Berdasarkan kegiatan yang dilakukan ini dapat disimpulkan bahwa edukasi yang dilakukan dapat meningkatkan pengetahuan generasi milenial tentang gaya hidup halal dan pemahaman tentang titik kritis keharaman makanan.

\section{DAFTAR PUSTAKA}

Ali, M. (2016). Konsep Makanan Halal dalam Tinjauan Syariah dan Tanggung Jawab Produk atas Produsen Industri Halal. AHKAM: Jurnal Ilmu Syariah, 16(2), 291-306. https://doi.org/https://doi.org/10.15408/ajis.v16i2.4459

Badan Pengawas Obat dan Makanan]. (2012). Peraturan Kepala BPOM Nomor HK.03.1.23.04.12.2205 tentang Pedoman Pemberian Sertifikat Produksi Pangan Industri Rumah Tangga. 1-6.

Guntarti A, Kumalasari ID, Susanti H. 2018. Pengenalan Kehalalan Produk dan Bahan Tambahan Makanan yang Berbahaya Bagi Kesehatan. SNIEMAS UAD.ISBN.978-6020737-07-2 LPPOM MUI, Halal Haram Gula Refinasi. Berita tanggal 12 September 2018. Diakses pada 24 Oktober 2020. [internert] Tersedia di www.halalmui.org/mui14/main/detail/halal-haram-gula- rafinasi.

Menteri Kesehatan Indonesia. 2012. Undang-Undang Republik Indonesia Nomor 33 Tahun 2012 tentang Bahan tambahan pangan dan sanksi hukum. Jakarta (ID): Sekretariat Negara

Mutmainah, L. (2018). The Role of Religiosity, Halal Awareness, Halal Certification, and Food Ingredients on Purchase Intention of Halal Food. Ihtifaz: Journal of Islamic Economics, Finance, and Banking, 1(1), 33. https://doi.org/10.12928/ijiefb.v1i1.284 
Nusran, Muhammad, et al (2015). Kebijakan Produk Halal dengan Simulasi Sistem Dinamik Untuk Meningkatkan Jumlah Produk bersertifikat Halal. PROSIDING SEMINAR NASIONAL TEKNOLOGI INDUSTRI III. ISBN :978-602-14822-2-3

Nusran, M., D Triana, S Raehana, H Damis, A Syarifudin, IS Wekke. (2018). Policy on Halal Slaughtering Availability for Halal Chicken Needs Makassar City Indonesia. International Journal of Engineering \& Technology 7 (4.29), hal.75 - 81.

Nusran, M ., Gunawan, M Razak, S Numba, IS Wekke. 2018. Halal Awareness on the Socialization of Halal Certification. IOP Conference Series: Earth and Environmental Science 175 (1), 012217. DOI: 10.1088/1755-1315/175/1/012217

Nusran, M., R Alam, D Triana, I Parakkasi, T Abdullah.(2019). Management of Supply Chain Process for Meat Products. Indonesian Journal of Halal Research, UIN Bandung, hal.18-25

Nusran, Muhammad (2019) Manajemen Penyembelihan Sistem Halal Produk Ayam Potong. Penerbit: Nas Media Pustaka,Makassar.( Management System of Halal Slaughter for Chicken Products. Publisher: Nas Media Pustaka, Makassar), 210 halaman

Pemerintah Indonesia. 1999. Undang-Undang Republik Indonesia Nomor 7 Tahun 1999 tentang Perlindungan konsumen. Lembaran RI Tahun 1999, No.7. Jakarta (ID): Sekretariat Negara

Pemerintah Indonesia. 2009. Undang-Undang Republik Indonesia Nomor 36 Tahun 2009 tentang kesehatan. Lembaran RI Tahun 2009, No.36. Jakarta (ID): Sekretariat Negara

Pemerintah Indonesia. 2012. Undang-Undang Republik Indonesia Nomor 18 Tahun 2012 tentang pangan. Lembaran RI Tahun 2012, No.18. Jakarta (ID): Sekretariat Negara

Pemerintah Indonesia. 2014. Undang-Undang Republik Indonesia Nomor 33 Tahun 2014 tentang Jaminan Produk Halal. Lembaran RI Tahun 2014, No33. Jakarta (ID): Sekretariat Negara

Ramlan, R., \& Nahrowi, N. (2014). Sertifikasi Halal Sebagai Penerapan Etika Bisnis Islami Dalam Upaya Perlindungan Bagi Konsumen Muslim. AHKAM : Jurnal Ilmu Syariah, 17(1), 145-154. https://doi.org/10.15408/ajis.v17i1.1251

Setiyani, L. (2014). Research Methods Information Technology. International Encyclopedia of Human Geography. https://doi.org/https://doi.org/10.1016/B978-0080449104.00180-2

Yasid, Farhan, F., \& Andriansyah, Y. (2016). Factors affecting Muslim students awareness of halal products in Yogyakarta, Indonesia. International Review of Management and Marketing, 6(4), 27-31.

Yunus, N. S. N. M., Rashid, W. E. W., Ariffin, N. M., \& Rashid, N. M. (2014). Muslim's Purchase Intention towards Non-Muslim's Halal Packaged Food Manufacturer. Procedia - Social and Behavioral Sciences, 130(May), 145-154. https://doi.org/10.1016/j.sbspro.2014.04.018. 